ve:ious factors which I will not go into, to mo it is fairly evident that this man is sulfering from an orelinary form of hysteria, and I am not inclined to think that it is other than thint. l'erhaps you will say thut that does not explain all of lis symptoms. Even so, I emmot account for this condition except an coming under the greneral classification of ordinary lyesteria.

Dr. Hanot, X. Morke, Chicago: This appears to be a new tind, or is at lestst a very lare symptom-grouping. With such exeptional finclings a certatin degree of modesty in suggesting a diannosis is becoming. There are artuin salient symptoms which are not axplainulue undes any theory that 1 know of regatring the association of symptoms: First, the swenting; me'cond. the presence of six million red colls; third, a marked eosinophilin; and fourth, a persistently elevated temperature These make a symptom-gromping that I have never seen associated. 'lhe case presents a new combination of symptoms, and possilly n mew disolder.

Dn. Groncis: A. Moleks, Jenver: I luve been very nuch interested in this case, but from the start it appeared to me on " functional busis. Someone has snid that nothing could be present in hysteria but what could be produced by sugges. tion. I would like to ask if sugrestion lans been used in this ense as a means of differential diagnosis. It has come within the experience of men who have used hypnotic suggestion that it is quite easy to produce oither loenlized or generul swenting to influence the temperature and produes other elinnges of cqually remarkable natures. However, that would not account for the hlood chunges which ocenr in this chse. The absence, however, of orgunic symptoms, or symptoms of tissue change, and the fuct that the functional disariangement which would produce or leat to the swenting can be peproduced by suggesfiom, loud me to believe that it is on a functional basis.

JR. F. E. MuRPIY, Kansas (ity, Mo.: May I ask when this estimute of eosinophils was made?

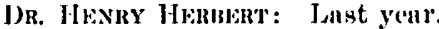

1)R. F. k. Mulsiry: lourteen per cent. of eosinophils is cartainly a symptom that necessitates some consideration. It would be interesting to know the percentuge of cosinophils at this time. Possibly a year ago there was an intestinal parasite or somothing of that sort giving eosinophils. It would be interesting to know at this particular time how much the nymptom observed a year ano is evidenced. There is one feat wre I ohserved, and that is the condition of this boy's vaseular system. Several of us palpated his blood-vessels, and there ure cortainly markol elanges in them. I am disposed to believe that there is somothing more than functional trouble in this instaner.

Dr. Hixky Henmart, los Angeles, ('al.: The temperature was taken regularly and always by the mouth for a period of from two to five mimutes. Suggestion lus not been used in this case. In regard to the eosinophils, that suggestion of resexumining the blood of the putient is a very good one. I tum at al loss to sily what the diagnosis is. One interesting fenture leads me to believe that it is a lesion of the third rympathetic ganglia: first. the intense pain on pressure; them,

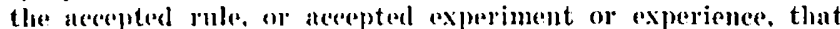
irritation of the sympathetie ganglia, especially of the third on one side shows a milnternl sweat, wherens the paralysis of that center shows anhidrosis. Now, we have general sweat ing on botl sides, pain on botl sides on pressure over the 1.) ird nimpathetic ganglia. At the same time, over that granglia in that approxintate region, or the region which is supplied by the approximate nerves. there is mbidrosis-no sweating at nll. 'Thut would indieate a general irritation of the swenting center and a paralysis of those nerves supplying that are-the suprasenpular region. If there is any process, filnosis or chronic inflummation, to furnish the ganglia with some pressure, that would aceount for that mulidrotic area, and at the sume time irritation of the entire sympathetic ganglia. The symptom-grouping, as one of the speakers mentioned, with the eosinophils, speaks against the supposition of afunetional disorder or hysterin. I think that symptom is based on a permanent disorder, probably a disorder of the nervons system

\section{HOW OUR THERAPEUTICS CAN BE IMPROVED *}

H()ARIMMAN REED, M.D. LOS ANGEI.ES

Tremenclous arkances have been male in therapentics doring the past two deandes, advances which it is needless to enumerate to educated merlical men. But the remains yet room for improvement. There are sted failures in treatment, many of which conld be avoth by a more perfect mastery of all the conditions whorconfront those charged with the high duty of endery by ing to lieal the sick. 'This can be attained onlyor raising the standard of the doetornte to a yet better plane, so as to assure for every practitioner a bence knowledge of all that pertains properly to the scienes. and art of healing and the auxilinry medical scienction. together with clinical cxperience under instructione Such a training with industry and patience would asch $\mathfrak{a}$ an accurate diagnosis in every case in which sussible diagnosis is practicable, followed by the best pose treatment

Tmprovement must result from a more thorough stirity of (1) man and his olgans and functions in both nore and discase, including especially diagnosis: ( 2 ) a mellies, intimate acquaintance with all the reliable renester mcdicinal, mechanical and psvchologic from what that source, a knowledge which shall reconnize the fact exting the more active ones seem to be capable of exe. either of two opposite actions according to the dose.

A very large proportion of the failures in treatinterwhether made by regulars, sectarians, quacks, congnosis. prescribers or self-closers, is due to a wrong diam when $\mathrm{N}_{0}$ method of treatment is likely to prove helptil wen it prescribed in the wrong case; very frequently the ding loes harn. Innumerable patients die because the daving mosis is made too late, the medical attendant mot loa and olstained needed counsel in time. Other fuilures iong often much mischief result from continuing to good and in large dose a remedy which may have done of to at first. Sometimes the firilure is in consequence cases small a dose havingr been prescribed. I have seen d d $0^{-}$ of hyperchlorliveluia and ulcer of the stomach or dion


bicarbonate and vet afterward promptly relieved the

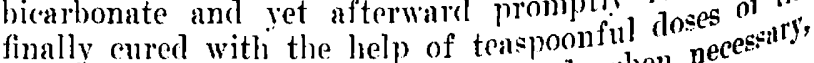
same diug wall diluted and combined, when necests with 30 to $40 \mathrm{gr}$. of bismutl.

On the other hand, while drop doses of the nerese iperac will relieve some forms of nausea, and solution. vomiting often yields to drop doses of Fowler stopped by a la Ringer, and a threatened miscarriage is stope salun the tincture of cimicifuga every hom in the fillo dars, dose, as I freguently proved in my general-practice p=ill any one who would try these medicines in them. doses in such cases would surely aggravate them.

Evidently, then, it would be a gain to our therapese if medical sturlents were plainly taught that op poite disturbing drugs are capable of producing op trate effects according to the dose. This was demono by afo to my own satisfaction twenty-three years nunperen carcful study of the elabornte reports of nogists in experiments conducted ly eminent pharmacolongons Fingland and Germany especially. My cof They were

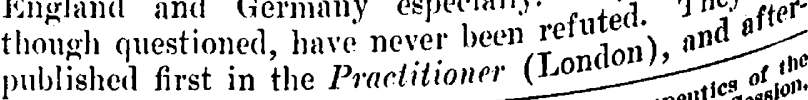

* Iread in the Sceticn on lpharmucology and Tha spual A Aceld at Los Angeles, June, 1911. 
"lird in this country. In a large experience since 1888 , summed as been amply confirmed. The matter was 1. A as follows:

the parts reitively small dose always at first stimulates branes or (nerve-centers, nerves, glands, muscles, mem2. A other tissues) which the drug specia!ly affects. alivays fufficiently large dose (puslied far enough) epecially affy paralyzes the parts which the drug 3. A affects.

and afterward or medium dose may first stimulate often enougrard depress, finally paralyzing if repented I.aucler

having stated inton was quoted in the same paper as action of stated in his "Pharmacology" that "this opposite of truth large and small doses seems to be the basis founded," foll which the doctrine of homeopathy was fallacies of But after Tahmemann.

is to have a all, the most important point in therapeutics 'Thousands a correct, an exact and also an early diagnosis. acid and of persons are to-kny taking hydrochloric that vague orin or some other exciting digestive aid for examination entity, "stomach trouble," when the proper" could only would slow hyperchlorhydria or ulcer which as many be made worse by any form of acid. Nenrly need a mole are being dosed with alkalies when they ing from contrary line of medication. Still others, sufferriscera-and atosis of one or more of the abdominal women-and their name is legion, especially among the drygs to receiving various lines of treatment from four-weeks' osteopathy and from Christian Science to a them wonld fast with no possible benefit, when most of organs replace relieved at once by having their displaced opelation leplaced and held up therenfter by either an properly for, as I have seen in liundreds of cases, by a - Instances fited abdominal supporter.

in cases in could be multiplicl indefinitely of failures no consultation the diagnosis was in doubt, and yet, Being no lon was had for economic or other reasons. speak plainlyer an aspirant for practice, I can afford to molonged dily and condem strongly any guessing or illness whed di]y-dallying about the nature of an obseure the doubt. Wha consultation would probably clear up refuse a When in such a case the patient or family $i_{1}$ retiringultation, the attendant would be justified fanily ask from it. When, on the other hand, the objects, he for a consultation and the medical attendant to make could have no cause for complaint if asked Probably for a broader-minded man. therapenties more open to improvement than in the anong of constipation. No affection is more common treated ineffectiveople and none is morc generally 8luggish bowetively. The resort to purgative drugs for seek medical ady is well-nigh universal. Patients rarely selves with advice for the trouble early but dose themaggravated. Eaxives till it has become chronic and curative treatien then, they will not often accept any such a treatment which involves time and expense, vibration course of massage, electricity or mechanical or a combination (especially intra-rectal), some one of which, in skilful hands of them, nearly always proves effective and regulated with the indispensable laxative diet cases. Doctors exerises, often even in chronic advanced that neither should warn such patients empliatically the constipation may render; and that, when continued very long, it incurable by any method.
The diet in most chronic affections is a factor of the very greatest consecyunce, A more thorough study of dietetics would immensely improve the therapeutics of the average practitioner of whatever school or system.

'Tlye modern exact methods in the diagnosis and treatment of gastro-enteric affections should receive more attention in our medical colleges. If every practitioner were required to master them, or not having done so, would seek help fiom specialists in that line, not only in his frankly stubborn abdominal cases, but also in countless otlser obscure affections, lie would very often be lielped sooner to find the key which would solve the difficulty and obviate a harmful prolonged dependence on hypmoties or other inappropriate drugs.

While iron and arsenic will generally cure anemia after the rause has been removed, quinin and arsenic nearly always cure true malaria, and mercury and the iodids have raredy failed to rid the system in time of syphilis, to say nothing of salvarsan, it would be woll if everybody, including practitioners of all sorts and the laity, could be impressed with the fact that many of the most powerful remedies are capable of doing ling in large or long-continued doses and that their safe and useful employment is often limited to the tiding over of emergencies or crises or the relief of intolerable pain, and that the cure can usually be accomplished only by a removal of the cause. In a very large proportion of chronic cases at least, the cause is some violation of lealth laws which demands a radical change in the patient's labits. Much of the present ineffective therapeutics results from attempts to cure people of maladies while they are continuing the bad habits which caused them.

No one can set bounds to the possibilities which may develop from the many new lines of treatment recently introluced, the antitoxins, the internal secretıons from various glands, cte. 'Jhe results already achieved with them afford great hopes for the future of therapentics.

After all, however, our best and most permanent cures will not result from drugs or other special lines of treatment alone, but from supplementing these by hygienic measures, by indueing our patients to live regular and temperate lives, eating and drinking simply and never to excess, chewing all food thoroughly, taking sufficient exercise and sleep, spending as much time as possible out in the open air and sunshine and, through abmdant ventilation night and day, breathing pure air whenever practicable.

Soutl Granada Avenue.

\section{CARCINOMA OF 'THE CLITORIS *}

CHARIES D. LOCKWOOD, M.D.

PASAUENA, CAL.

Tumors of the clitoris are of infrequent occurrence, and malignant tumors are rare. The histopathologic study of these tumors has been neglected, and many of the reported cases are not accompanied by a pathologic report. I wish to report a case.

Patient.-Mrs. K., aged 70, mother of two children, healthy, except for her present complaint. For six years she has suf. fered from painful micturition and irritation about the vulva. For the past year the pain on urination has been almost intol-

- Ifeald In the Section on Obstetries and Gynecology of the Amirican Medical Association, at the Sixty-Second Annual Session, held at I os Angeles. June, 1011.

- Because of lack of space the reviow of the llterature is here omitted. It is given complete in the Transactions of the Section. 